\title{
Interaction for Innovation: Comparing Norwegian Regions
}

\author{
Marina Solesvik*, Magnus Gulbrandsen ${ }^{* *}$
}

\begin{abstract}
Building upon insights from earlier investigations of innovation collaboration from a regional perspective as well as the triple helix perspective, local/regional innovation systems and open innovation approaches, this study explores whether cooperation between firms, universities and government increases the intensity of innovation equally for the capital city and peripheral regions. We investigate whether firms located in the capital region benefit more from public support, cooperation with universities, and cooperation with different stakeholders than firms located in peripheral regions. Using logistic binary regressions, we find that capital region firms are generally not more innovative than those located elsewhere. We also find no effect on innovation from cooperation with universities, although public support is related to engagement in product and process innovations. Our results warn against simple applications of triple helix and open innovation approaches, as many forms of collaboration seem to have little impact on innovation, regardless of regional context.

Keywords: innovation, cooperation, triple helix model, regional innovation systems, Norway.
\end{abstract}

\section{INTRODUCTION}

The need for innovation has been highlighted by policymakers worldwide, believing that this is important for the competitiveness of firms and wider social and economic benefits for the regions where the firms are found. OECD has in particular highlighted the need to establish good framework conditions to ensure collaboration between firms and other actors at regional, national and international levels (e.g. OECD, 2008 on Norway). Innovation is a collective process which occurs in a system where geography, regional organization and proximity are important factors in order to understand successful innovation processes (Asheim and Gertler, 2005; Laursen et al., 2011; Laursen et al. 2012a and b; Herstad et al., 2014). Research and innovation policy at the

\footnotetext{
* Marina Solesvik, Professor Dr, Stord/Haugesund University College, Bjørnsonsgate 45, 5528 Haugesund, Norway; Bergen University College, P.O. Box 7030, Nygårdsgaten 112, 5020 Bergen, Norway, tel.: +47 48 133 882, mzs@hsh.no. ** Magnus Gulbrandsen, Professor Dr, Center for Technology, Innovation and Culture (TIK), University of Oslo, Postbox 1108 Blindern, 0317 Oslo, Norway, tel.: +47 48133 882, magnus.gulbrandsen@tik.uio.no.
} 
regional level is complicated, especially in small open economies where the regional administrative level has limited political influence and resources. Complexity related to the number of industries, heterogeneity in firm size and other aspects are often almost equal at regional and national levels. At the same time, there are often significant $R \& D$ resources at the regional level and often several potentially strong industrial clusters, which makes it relevant to explore the impact of collaboration patterns and policy support at the regional level.

With the series of Community Innovation Survey (CIS) data emerging from many different European countries, much insight has been gained into the dilemmas confronting firms when it comes to innovation collaboration, openness and various forms of local and regional linkages and spillover effects. Still, the relationship between innovation results and collaboration are debated, and calls have been made for more studies of various facets of this relationship (Laursen and Salter, 2006; Herstad et al., 2011). In this article, we study geographical patterns of innovation collaboration in cityregions in Norway, a small open economy in Northern Europe, and we will in particular focus on relationships between firms and universities and on the role of public support for innovation.

On a conceptual level, both the triple helix model (Etzkowitz and Leydesdorff, 1997 and 2000) and regional innovation system perspectives (Asheim and Coenen, 2005; Asheim and Gertler, 2005; Asheim, 2007) emphasize how economic and social development occurs in close cooperation between governments, industries and universities. New organizations, norms and forms of cooperation emerge from cooperation between these three spheres of society, often within specific regions and cities. These perspectives are well suited as a backdrop to exploring cooperation between research environments, government support mechanisms, and industrial firms. The perspectives concentrate on heterogeneity and how regional governments can contribute to innovation by stimulating development of networks, clusters and cooperation.

Our investigation is a follow-up of earlier Norwegian empirical studies, especially ones looking at differences between regions/cities in the country (Strand and Leydesdorff, 2013; Herstad et al., 2014). We use CIS data to explore the following questions: (1) How does cooperation with different actors affect innovation in firms? (2) Are firms which cooperate with universities more likely to report differently on innovativeness than firms which do not cooperate with them? (3) Are firms which get public support more likely to report differently on innovativeness than those which do not get support?

The paper has several contributions. First, we add to the literature on innovation interaction by further exploring university-industry-government 
collaboration and its relationship to different types of innovation. Whereas the empirical literature on the triple helix model is limited, we further develop the concept of the triple helix to see whether cooperation between three helices is equally efficient for two different types of innovation (product and process). Second, we contribute to the literature on open innovation/ collaboration by studying whether open innovation leads to more intensive innovation involvement, particularly for firms located in the capital region. We also add to the literature on regional innovation, and similar to Herstad et al. (2014), we find that firms located in the capital region are generally not more innovative than other firms, which may be a particular characteristic of Norway.

The paper is organized as follows: First, we discuss existing theoretical and empirical literature. From this we assume that participation of different actors in the firm's environment may assist a firm in accumulating innovation capability which increases its innovation intensity. Second, we discuss the sample and the methodology used to test the hypotheses. Information was gathered from a sample of the Norwegian firms which participated in the Community Innovation Survey (CIS) 2010 organized by Statistics Norway. Participation in CIS is compulsory in Norway. Third, we report the results from binary logistic analysis relating to links between cooperation patterns and innovation involvement. Fourth, we discuss our key findings and present suggestions for additional research. Implications for stakeholders involved are also discussed, along with some final conclusions.

\section{THEORETICAL AND EMPIRICAL INSIGHTS}

Cooperation is related to innovation involvement (Afuah, 2000; Solesvik and Gulbrandsen, 2013), and a general finding from more than a decade of Community Innovation Surveys is the strong collaborative patterns of innovative firms. In the triple helix perspective, the role of universities is particularly highlighted, as it is argued that universities contribute significantly to innovation processes in different regions (Etzkowitz and Leydesdorff, 1997 and 2000). There are famous global success examples such as the Silicon Valley (Fritsch and Schwirten, 1999), Route 128 (Dorfman, 1988), Austin \& San Antonio Corridor (Smilor et al., 1988), or the Cambridge region in the United Kingdom (Segal, 1988).

The general argument is that the high level of cooperation between actors in the region is crucial for the performance of the regional innovation systems. Universities are responsible for innovation, new technology and product development in one third of Training and Enterprise Councils in the UK (Huggins, 1998). The triple helix model highlights how university- 
industry-government cooperation seems to lead to innovation in dynamic and heterogeneous linkages because universities are conceptualized as "knowledge hubs" which provide research, education of young people, and knowledge transfer (Mitra, 2012), often in their particular regions. Universities are "influential actors and equal partners in a triple helix of university-industrygovernment relations" (Etzkowitz, 2003: 295). They supply both qualified staff for firms and organizations and contribute to innovation development. Success of knowledge transfer from university to firms depends on the state of the economy (Mitra, 2012) and absorptive capacity of firms to take in new knowledge from the university (Clausen, 2013).

Universities differ; some are research-intensive, others are teachingintensive. Research-intensive universities are important suppliers of fundamental and blue-sky knowledge, as well as applicable technologies for industry (Mitra, 2012). Thus, larger cities and their metropolitan areas benefit more from their universities in terms of innovation than smaller cities and towns having teaching-intensive universities in their regions (Gulbrandsen and Solesvik, 2012). The triple helix authors highlight an array of indicators used to measure effectiveness of university-industry-government relations, such as generation of social, human and intellectual capital (Mitra, 2012), and regional economic development (Etzkowitz, 2003). Empirical investigations from the UK show how patterns of collaboration between firms and universities are complex and based not just on geographical proximity (which only matters for some types of relations) but also on perceived quality of the university involved (Laursen et al., 2011). German investigations have questioned the strong emphasis on R\&D collaboration, finding that this only weakly affects innovation and regional knowledge spillovers (Fritsch and Franke, 2004).

Studies investigating the influence of public support of R\&D on innovation have been reviewed earlier (Productivity Commission, 2007). The majority of studies found positive effect of public support on the number of firms introducing innovation, on increased radical and incremental innovation (Hewitt-Dundas and Roper, 2010), enhancing firm's innovation activities (Almus and Czarnitzki, 2003), and improving market sector productivity (Haskel and Wallis, 2013). A brief comparative study (Johansen et al., 2013), however, found mixed results related to the Norwegian regions regarding the influence of the public support. In some regions, the positive effect of public support was observed, while in other regions, the effect of public support was not very significant and public innovation support programs have not promoted high-scale innovation development among the participating firms. This issue needs to be explored closer.

Learning and Innovation in Space, Arne Isaksen, James Karlsen, Marta Gancarczyk (Eds.) 
This discussion leads us to suggest the following hypotheses:

\section{Hypothesis 1:}

There is a positive relationship between (a) public support of R\&D, (b) firms' cooperation with universities and high intensity of product innovation.

\section{Hypothesis 2:}

There is a positive relationship between (a) public support of R\&D, (b) firms' cooperation with universities and high intensity of process innovation.

What is referred to as "open innovation" (Chesbrough, 2003), i.e. a strong collaborative orientation in firms, is widely assumed to enhance innovation involvement, similar to the arguments of the triple helix perspective. Firms enhance their innovativeness by exploiting external knowledge which is disseminated through different actors (Tether, 2002) and available through various channels (Howells et al., 2003; Spithoven et al., 2010). Some advanced firms create favorable conditions for development of innovative ideas internally. Employees are considered as an important source of innovation and in some cases innovation circles are created. Job rotations and interdisciplinary teams inside the firm also serve the dissemination of knowledge, skills, and information inside the firm (Burton and Obel, 2004; Laursen, 2003).

Another source of innovative ideas are customers (Afuah, 2000), suppliers and competitors (Afuah, 2000; Ahuja, 2000; von Hippel, 1988), who are considered as not passive recipients of products but co-creators of innovative products. Even when customers, suppliers and competitors are not direct sources of innovation, they are still very important actors in information sharing (Afuah, 2000). New business models suggested that innovative firms rely more and more on various forms of external consultants related to innovation and even on competitors (Laursen and Salter, 2006).

It is argued that firms should be ready for open innovation, i.e. possess educated employees with absorptive capacity in order to understand and apply ideas proposed from outsiders and be ready to quickly commercialize viable ideas. Learning and collaboration orientation of the firm increases the benefits from open innovation (Reichwald and Piller, 2009). Organizational and cultural characteristics are important for implementing open innovation. Firms use significant amounts of time, money and other resources to find new innovative opportunities (Laursen and Salter, 2006). Finding open innovation partners is possible through networking. However, small firms owners and managers often have no time to participate in meetings in 
network organizations. Small firms also score relatively low in terms of absorptive capacity (Spithoven et al., 2010). Laursen and Salter (2006: 131) found that "those who search widely and deeply - tend to be more innovative". However, several more methodologically rigorous studies have found a negative relationship between too much openness and innovation performance (Enkel et al., 2009; Laursen and Salter, 2004; Vahter et al., 2012). A Norwegian investigation found that there are different strategies of openness, concluding that firms should strive to maintain "organizational contexts" and build competences rather than blindly follow a general collaborative orientation (Ebersberger and Herstad, 2011). This discussion leads us to suggest the following hypotheses:

Hypothesis 3: There is a positive relationship between firm's cooperation with (a) clients, (b) suppliers, (c) competitors, (d) consultants and high intensity of product innovation.

Hypothesis 4: There is a positive relationship between firm's cooperation with (a) clients, (b) suppliers, (c) competitors, (d) consultants and high intensity of process innovation.

Hypothesis 5: There is a positive relationship between firm's use of (a) internal sources, (b) professional sources, and (c) university sources of information and high intensity of product innovation.

Hypothesis 6: There is a positive relationship between firm's use of (a) internal sources, (b) professional sources, and (c) university sources of information and high intensity of process innovation.

Several large-scale Italian investigations found that the level of social ties in a region strongly determines the collaboration patterns and the benefits that firm derive from collaboration for innovation (Laursen et al., 2012a and b). This and other empirical studies highlight the heterogeneity of regions. In Denmark and several other countries firms located in the capital metropolitan area are considered as more innovative than firms in the peripheral regions (European Union, 2014). One possible explanation is that capital regions have strong research and development institutions. Lester (2005) suggests that R\&D environments can be a creative meeting spot in the leading cities. However, several studies of Norwegian firms using different types of data have failed to find any significant difference between the Oslo metropolitan area and other Norwegian regions in terms of innovation activity in general (Herstad et al., 2011; Strand and Leydesdorff, 2013). Herstad et al. (2011) study was that 
they considered innovation activity of Norwegian firms in general, and an interesting follow-up is to see how different patterns of collaboration affect different types of innovation. Florida (2002) argues that in this context highly educated, entrepreneurially oriented and innovative employees are important for growth and innovation. A well educated population, population which is heterogeneous with respect for individual differences and choices, and well developed infrastructure are typical aspects and competitive advantages of capital regions. On the other hand, capital regions are often larger than other regions, and that is why there will be many more organizations and actors leading to coordination challenges. The size of the region influences other aspects as well, for example, related to social capital (Putnam, 1993), i.e. what types of informal social ties exist across organizational and sectoral borders. It can be assumed that there are more informal meeting arenas in the small regions or more heterogeneous forms of social capital. The Oslo and Akershus region scores lower in terms of cooperation than other regions in Herstad et al. (2011). On the other hand, a later Norwegian investigation of knowledge-intensive business services, found to be important facilitators in collaborative networks, highlights the central role of the capital region and the weak contexts found in many smaller city-regions (Herstad and Ebersberger, 2013).

Finally, it can be added that regional collaboration is not just related to local spillovers and effects. A recent Norwegian study argues that the innovation networks of firms are global, where local knowledge bases (Asheim and Coenen 2005) affect the participation of firms in what is referred to as "global innovation networks" (Herstad et al., 2014). We suggest the following hypotheses:

Hypothesis 7: The relationship between public support of R\&D and intensity of innovation is moderated by regional context such that there is a different degree of influence of R\&D public support on innovation development in different regions.

Hypothesis 8: The relationship between cooperation between firms and universities and intensity of innovation is moderated by the regional context such that there are different influences on cooperation between firms and universities on innovation development in different regions. 


\section{ReSeARCh Method AND DATA}

\section{Sample, data collection and respondents}

To test our hypotheses, we used primary information from the Community Innovation Survey collected by Statistics Norway. Data collection was undertaken with a questionnaire administrated in Norwegian. In Norway, answering $\mathrm{ClS}$ survey is compulsory for firms with more than five employees; with a stratified sample of firms with fewer than 50 employees and the full population of firms with more than 50 . Not answering the CIS survey will lead to penalties to enterprises and the response rate is more than 90 per cent. The European CIS survey is a cross-country study which uses the same questionnaire and is administered semi-annually in the EU member countries. We used data from CIS2010 to answer the research questions of this study. Altogether 6595 valid answers were obtained in Norway. 1503 (22.8\%) respondents from the total sample indicated that they innovated. The distribution of the sample by sectors is given in Table 1 .

Table 1. Sectoral break down of sample $(n=1503)$

\begin{tabular}{lccc}
\hline Sectors & $\begin{array}{c}\text { Firms with } \\
\text { innovation }\end{array}$ & $\begin{array}{c}\text { Product } \\
\text { innovation }\end{array}$ & $\begin{array}{c}\text { Process } \\
\text { innovation }\end{array}$ \\
\hline Agriculture \& fisheries & $1.9 \%$ & $81.8 \%$ & $68.2 \%$ \\
Mining \& quarrying & $2.9 \%$ & $74.1 \%$ & $69.0 \%$ \\
Industry & $45.4 \%$ & $73.2 \%$ & $70.3 \%$ \\
Electo \& natural gas supply & $1.8 \%$ & $62.5 \%$ & $50.0 \%$ \\
Water and drain & $1.3 \%$ & $60.0 \%$ & $27.3 \%$ \\
Construction & $2.1 \%$ & $53.6 \%$ & $28.8 \%$ \\
Car sale & $5.9 \%$ & $39.9 \%$ & $43.8 \%$ \\
Transport \& warehousing & $1.7 \%$ & $41.7 \%$ & $20.7 \%$ \\
Hotels \& catering & $0.2 \%$ & $5 \%$ & $4.3 \%$ \\
ICT & $19.9 \%$ & $76.6 \%$ & $71.7 \%$ \\
Finance & $1.8 \%$ & $34.1 \%$ & $45.2 \%$ \\
Consulting and R\&D services & $14.1 \%$ & $78.8 \%$ & $68.9 \%$ \\
Business services & $0.9 \%$ & $50.0 \%$ & $33.3 \%$ \\
Culture & $0.2 \%$ & $40.0 \%$ & $66.7 \%$ \\
Total & $100 \%$ & $67.6 \%$ & $61.1 \%$ \\
\hline
\end{tabular}

We have followed standard industrial classification SIC 2007 (SSB, 2014). We used only respondents who innovated to test our hypotheses. There 
were 468 respondents from the Oslo and Akershus region. There were 143 respondents from Bergen and Hordaland county, 151 respondents from Stavanger and Rogaland county; 105 respondents from Trondheim and Trondelag county, 45 respondents from Kristiansand and Agder county, 36 from Troms $\varnothing$ and Troms county, and 555 from the rest of the country. It is somewhat difficult to estimate correctly the location of the firm because firms might have offices in several regions and countries. This is methodological limitation of the CIS. We estimate location according the data provided in the survey.

\section{Sample representation}

The sample comprises only firms with 5 and more employees. The mean size was $161.97(S D=629.36)$.

\section{Dependent variables}

Innovation developed and introduced by firms was measured using several variables. We measured innovation introduced in the functional areas: product and process innovation.

Product innovation. The respondents were presented with the following two statements to measure product innovation: Has the firm introduced products (goods or services) in the market which are new or significantly improved for the firm in 2008-2010, and has the firm introduced products in the market which are not just new or improved for the firm, but also for the firm's market in the period 2008-2010? With regard to each statement, firms which introduced new products were allocated a score of ' 1 ', and those not introduced new products assigned a score of ' 0 '. We summated scores such that the maximum value for product innovation was 2 . For the binary logistic analysis, we then allocated a value of ' 1 ' for summated scores 1 and 2 , and a value of ' 0 ' for scores of 0 (Product I).

Process innovation. The respondents were presented with the following three statements related to introduction of process innovation in 2008-2010: (a) new or significantly improved methods of production or processing of goods or services; (b) new or significantly improved methods of storage, delivery, or distribution of goods or services; and (c) new or significantly improved methods of support, such as systems of maintenance, purchase, accounting or IT. With regard to each statement, firms which introduced new products were allocated a score of ' 1 ', and those not introduced new processes assigned a score of ' 0 '. We summated scores such that the maximum value for process innovation was 3 . For the binary logistic analysis, we then allocated 
a value of ' 1 ' for summated scores 1,2 and 3, and a value of ' 0 ' for scores of 0 (Process I).

\section{Independent variables}

Types of cooperation partners. We have checked for the cooperation with various actors, i.e. (1) cooperation with suppliers (C. suppl.); (2) cooperation with clients (C. clients); (3) cooperation with competitors (C. compet.); (4) cooperation with consultants (C. consult.); and (5) cooperation with universities (C. univers.).

Knowledge sources. Respondents were presented with the following statement related to the sources of knowledge: Please indicate the sources of knowledge or information used in your innovation activities, and their importance during the period 2008-2010. Following Mol and Birkinshaw (2009), we divided knowledge sources into three variables, i.e. internal sources, university sources, and professional sources. Internal sources (Int. sources) included sources (a) within the enterprise, (b) other enterprises within the enterprise group. Professional sources (Prof. sources) included (a) professional conferences, meetings, (b) trade associations, (c) fairs, exhibitions. University sources (Univ. sources) included sources of R\&D information from universities and university colleges. For each type of knowledge sources, the value of ' 1 ' was allocated for firms that had used a knowledge source, the value of ' 0 ' was allocated for firms that had not used a particular knowledge source.

Public support. Governmental support is an important part of the triple helix model. The Norwegian national and regional authorities have introduced a number of funds and special programs aimed to support innovation development. Firms were allocated the value of ' 1 ' if they have used any of the following support funds (a) Norwegian Research Council; (b) Skattefunn (tax reduction scheme); (c) Innovation Norway; (d) ministry, directorate, regional government, local community or other similar source; and (e) EU finance (Support).

\section{Control variables}

Firm size. Firm size might influence on the innovation behavior of firms. The variable is calculated as the logarithm of the number of employees (Size).

Patents. Firms which have patented their products were allocated a score of ' 1 ', otherwise they were allocated a score of ' 0 ' (Patents).

Major regions. The study's aim is to compare innovation behavior of firms in the capital region and five major regions of Norway around biggest cities, i.e. Bergen, Stavanger, Trondheim, Kristiansand and Troms $\varnothing$ areas. 
All these are university towns and with significant industry presence. We introduced six dummy variables for each region. Firms situated in the Oslo and the Akershus region around it were allocated the value of ' 1 ', otherwise a value of ' 0 ' (Oslo). Firms situated in Bergen and Hordaland region around it were allocated the value of ' 1 ', otherwise a value of ' 0 ' (Bergen). Firms situated in Stavanger and Rogaland region around were allocated the value of ' 1 ', otherwise a value of ' 0 ' (Stavanger). Firms situated in Trondheim and Trondelag region around were allocated the value of ' 1 ', otherwise a value of ' 0 ' (Trondheim). Firms situated in Kristiansand and the surrounding Agder region were allocated the value of ' 1 ', otherwise a value of ' 0 ' (Kristiansand). Firms situated in Troms $\varnothing$ and Troms region around were allocated a value of ' 1 ', otherwise a value of ' 0 ' (Tromso).

\section{RESULTS}

Variables means, standard deviations, and correlations coefficients are reported in Table 2.

Binary logistic regression analysis was used to test our hypotheses. Table 3 shows the results of our analyses.

Model 1 is the model reporting main effects of control variables on product innovation. Those who had registered patents (Patents) were significantly more likely to report product innovation ( $p<0.001)$. Those who have received public support from Innovation Norway, EU, Research Council of Norway, or local governments (Support) $(p<0.05)$ were significantly more likely to report a high intensity of product innovation. Hypothesis $1 \mathrm{a}$ is supported. Additionally, firm's size is negatively and significantly $(p<0.001)$ related to innovation, i.e. smaller firms are more innovative. Firms situated in Kristiansand region are significantly $(p<0.05)$ less innovative in terms of product innovation.

Model 2 is the model reporting main effects of independent variables on product innovation. Cooperation with universities is negatively and significantly $(p<0.01)$ related to product innovation. Hypothesis $1 \mathrm{~b}$ is not supported. Cooperation with clients is positively and significantly $(p<0.001)$ related to product innovation. Hypothesis $3 a$ is supported. Cooperation with suppliers, competitors and consultants is not significantly related to product innovation. Hypotheses $3 \mathrm{~b}-\mathrm{d}$ are rejected. Those who used professional sources of information reported significantly $(p<0.05)$ higher level of product innovation. Hypothesis $5 b$ is supported. Use of internal and university sources is not significantly related to product innovation. Hypotheses $5 \mathrm{a}$ and $5 \mathrm{c}$ are rejected. 


\begin{tabular}{|c|c|c|c|c|c|c|c|c|c|c|c|c|c|c|c|c|c|c|c|c|c|}
\hline Variables & Mean & SD & 1 & 2 & 3 & 4 & 5 & 6 & 7 & 8 & 9 & 10 & 11 & 12 & 13 & 14 & 15 & 16 & 17 & 18 & 19 \\
\hline 1. Size (In) & 1.74 & .52 & 1.00 & & & & & & & & & & & & & & & & & & \\
\hline 2. Patents & .95 & .23 & .01 & 1.00 & & & & & & & & & & & & & & & & & \\
\hline 3. Support & .34 & .47 & $-.15^{* *}$ & .00 & 1.00 & & & & & & & & & & & & & & & & \\
\hline 4. Oslo & .32 & .47 & .11 & .02 & -.01 & 1.00 & & & & & & & & & & & & & & & \\
\hline 5. Bergen & .10 & .29 & -.02 & -.04 & -.02 & $-.22^{* * *}$ & 1.00 & & & & & & & & & & & & & & \\
\hline 6. Stavanger & .10 & .30 & .03 & -.03 & -.04 & $-.23^{* * *}$ & $-.11^{* * *}$ & 1.00 & & & & & & & & & & & & & \\
\hline 7. Trondheim & .06 & .24 & $-.06^{*}$ & .00 & .03 & $-.18^{* * *}$ & $-.08^{* *}$ & $-.09^{* *}$ & 1.00 & & & & & & & & & & & & \\
\hline 8. Kristians. & .03 & .17 & .02 & -.01 & -.01 & $-.12^{* * *}$ & $-.06^{*}$ & -.06 & -.05 & 1.00 & & & & & & & & & & & \\
\hline 9. Troms $\varnothing$ & .02 & .14 & -.04 & .02 & .04 & $-.10^{* * *}$ & -.05 & -.05 & -.04 & -.02 & 1.00 & & & & & & & & & & \\
\hline 10. C. suppl. & .21 & .41 & $.14^{* *}$ & .04 & $.13^{* * *}$ & -.04 & -.02 & .01 & .01 & .01 & .02 & 1.00 & & & & & & & & & \\
\hline 11. C. clients & .23 & .42 & $.10^{* *}$ & .05 & $.06^{*}$ & -.04 & -.04 & .01 & .01 & -.01 & .03 & $.52^{* * *}$ & 1.00 & & & & & & & & \\
\hline 12. C.compet. & .09 & .29 & $.11^{* *}$ & .04 & .04 & .01 & -.01 & .01 & -.02 & -.01 & .04 & $.43^{* * *}$ & $.46^{* * *}$ & 1.00 & & & & & & & \\
\hline 13. C. consult & .15 & .35 & $.09^{*}$ & .03 & $.08^{*}$ & .01 & .01 & -.01 & -.02 & .01 & $.06^{*}$ & $.47^{* * *}$ & $.48^{* * *}$ & $.47^{* * *}$ & 1.00 & & & & & & \\
\hline 14. C. univers. & .17 & .38 & $.18^{* *}$ & .04 & $.12^{*}$ & .01 & $-.03^{*}$ & -.02 & .05 & .03 & .03 & $.48^{* *}$ & $.47^{* * *}$ & $.43^{* * *}$ & $.47^{* * *}$ & 1.00 & & & & & \\
\hline 15.Int.sources & .95 & .22 & .04 & $.24^{* *}$ & .00 & .01 & -.02 & .02 & -.02 & .01 & -.01 & .05 & .05 & .03 & .03 & $.41^{* * *}$ & 1.00 & & & & \\
\hline 16.Prof.sources & .91 & .29 & .01 & $.19^{* *}$ & .02 & -.01 & .02 & -.04 & -.01 & -.01 & .02 & $.09^{* *}$ & $.10^{* *}$ & $.08^{* *}$ & $.09^{* *}$ & $.08^{* *}$ & $.08^{* *}$ & 1.00 & & & \\
\hline 17.Univ.sources & .68 & .46 & $.09^{*}$ & $.06^{*}$ & .07 & -.05 & -.02 & -.03 & .03 & -.01 & .06 & .17 & $.17^{* * *}$ & $.14^{* * *}$ & $.14^{* * *}$ & $.24^{* * *}$ & $.14^{* * *}$ & $.34^{* * *}$ & 1.00 & & \\
\hline 18. Product I. & .63 & .49 & $-.08^{* *}$ & .05 & $.11^{* * *}$ & .06 & .03 & -.04 & -.01 & -.06 & -.01 & $.07^{*}$ & $.14^{* * *}$ & $.14^{* * *}$ & .03 & -.01 & $.14^{* * *}$ & $.11^{* * *}$ & .03 & 1.00 & \\
\hline 19. Process I. & .46 & .50 & .03 & .05 & .04 & -.02 & -.02 & .02 & -.01 & -.02 & -.01 & $.14^{* * *}$ & $.13^{* * *}$ & $.13^{* * *}$ & $.10^{* * *}$ & $.09^{* *}$ & $.13^{* * *}$ & $.05^{*}$ & .01 & $.08^{* *}$ & 1.00 \\
\hline
\end{tabular}


Table 3. Results of the binary logistic analysis for predicting types of innovation ( $n=1503) a$

\begin{tabular}{|c|c|c|c|c|}
\hline $\begin{array}{l}\text { Dependent variable: } \\
\text { mindset }\end{array}$ & $\begin{array}{l}\text { Model 1: } \\
\text { Product } \\
\text { innovation }\end{array}$ & $\begin{array}{l}\text { Model 2: } \\
\text { Product } \\
\text { innovation }\end{array}$ & $\begin{array}{l}\text { Model 3: } \\
\text { Process } \\
\text { innovation }\end{array}$ & $\begin{array}{l}\text { Model 4: } \\
\text { Process } \\
\text { innovation }\end{array}$ \\
\hline \multicolumn{5}{|l|}{ Controls } \\
\hline & $-.515 * * *$ & $-.590 * * *$ & -.048 & -.168 \\
\hline \multirow[t]{2}{*}{ Size (log) } & (.099) & $(.111)$ & $(.094)$ & (.104) \\
\hline & $1.186 * * *$ & $1.021 * * *$ & $.473 * * *$ & $.340^{*}$ \\
\hline \multirow[t]{2}{*}{ Patents } & $(.121)$ & $(.141)$ & $(.115)$ & $(.138)$ \\
\hline & $.252 *$ & $.246 *$ & $.181^{* * *}$ & .116 \\
\hline \multirow[t]{2}{*}{ Public support } & $(.116)$ & $(.120)$ & $(.108)$ & $(.111)$ \\
\hline & .162 & .258 & -.164 & -.099 \\
\hline \multirow[t]{2}{*}{ Oslo } & $(.140)$ & $(.143)$ & $(.128)$ & $(.132)$ \\
\hline & .134 & .269 & -.135 & -.052 \\
\hline \multirow[t]{2}{*}{ Bergen } & $(.207)$ & $(.213)$ & (.191) & $(.196)$ \\
\hline & -.309 & -.256 & .021 & .047 \\
\hline Stavanger & (.197) & $(.202)$ & $(.186)$ & $(.190)$ \\
\hline \multirow[t]{3}{*}{ Trondheim } & .207 & .319 & -.412 & -.376 \\
\hline & $(.242)$ & $(.246)$ & $(.222)$ & $(.227)$ \\
\hline & $-.717^{*}$ & -.618 & -.137 & -.102 \\
\hline \multirow[t]{2}{*}{ Kristiansand } & $(.327)$ & $(.336)$ & $(.317)$ & $(.324)$ \\
\hline & -.005 & -.029 & .042 & .083 \\
\hline Tromso & $(.384)$ & $(.390)$ & $(.329)$ & $(.360)$ \\
\hline \multicolumn{5}{|l|}{ Independent } \\
\hline \multirow{2}{*}{ Coop suppliers } & & .209 & & $.609 * * *$ \\
\hline & & $(.180)$ & & $(.158)$ \\
\hline \multirow{2}{*}{ Coop clients } & & $.915^{* * *}$ & & .177 \\
\hline & & $(.193)$ & & $(.164)$ \\
\hline \multirow[t]{2}{*}{ Coop competitors } & & .060 & & .262 \\
\hline & & $(.232)$ & & $(.204)$ \\
\hline \multirow{2}{*}{ Coop consultants } & & -.275 & & .079 \\
\hline & & $(.190)$ & & $(.168)$ \\
\hline Coop universities & & $-0.553 * *(.190$ & & $\begin{array}{l}.012 \\
(.163)\end{array}$ \\
\hline \multirow{2}{*}{ Internal sources } & & .016 & & .108 \\
\hline & & $(.302)$ & & $(.294)$ \\
\hline \multirow{3}{*}{ Proffes. sources } & & $.576^{*}$ & & .130 \\
\hline & & $(.232)$ & & $(.270)$ \\
\hline & & -.267 & & -.144 \\
\hline University sources & & $(.168)$ & & $(.150)$ \\
\hline \multirow{2}{*}{ Constant } & $.629 * *$ & .401 & $-.488 *$ & $-.566 * *$ \\
\hline & (.199) & $(.213)$ & $(.192)$ & $(.208)$ \\
\hline-2 log likelihood & 1805.341 & 1758.113 & 2031.213 & 1981.326 \\
\hline$\%$ correctly classified & 69.6 & 70.2 & 57.7 & 60.8 \\
\hline
\end{tabular}

a) Standardized beta regression coefficients $* p<0.05 ;{ }^{* *} p<0.01 ;{ }^{* * *} p<0.0$

Model 3 is the model reporting main effects of control variables on process innovation. Those who had registered patents (Patents) were significantly more likely to report process innovation $(p<0.001)$. Those with 
public support (Public support) ( $p<0.001$ ) were significantly more likely to report a high intensity of process innovation. Hypothesis $2 a$ is supported. Location of the firms was not significant for process innovation. Model 4 is the model reporting main effects of independent variables on process innovation. Cooperation with universities is not significantly $(p<0.01)$ related to process innovation. Hypothesis $2 b$ is not supported. Cooperation with suppliers is positively and significantly $(p<0.001)$ related to process innovation. Hypothesis $4 \mathrm{~b}$ is supported. Cooperation with clients, competitors and consultants is not significantly related to process innovation. Hypotheses $4 a, 4 c$ and $4 d$ are rejected. Use of internal, professional and university sources is not significantly related to process innovation. Hypotheses $6 a-6 c$ are rejected.

Six interaction variables relating to moderating role of the region were included in the models (Support*Oslo, Support*Bergen, Support*Stavanger, Support*Trondheim, Support*Kristiansand, Support*Tromso). We run binary logistic regressions to test Hypothesis 7. None of these interaction terms was significant. We have not reported them in Table 3 in order to save space but the results are available from the authors. Hypothesis 7 is not supported.

Six interaction variables relating to moderating role of the region between cooperation with university and innovation development were included in the models (C. univers.*Oslo, C. univers. *Bergen, C. univers. ${ }^{*}$ Stavanger, C. univers. ${ }^{*}$ Trondheim, C. univers. ${ }^{*}$ Kristiansand, C. univers. ${ }^{*}$ Tromso). We run binary logistic regressions to test Hypothesis 8 . None of these interaction terms was significant. We have not reported them in Table 3 in order to save space but the results are available from the authors. Hypothesis 8 is not supported.

\section{DISCUSSION}

This study expands several earlier investigations of innovation collaboration from a city region perspective, several of which have explored related issues in Norway. Data was gathered from a sample of Norwegian firms with 5 and more employees (CIS 2010). The analysis has confirmed that both innovation and cooperation are multi-dimensional concepts, and specific dimensions of innovation and cooperation need to be considered on their own.

Results from the binary logistic regression analysis suggests that firms situated in the capital region of Norway do not score higher in product and process innovation. Studies have warned that firms in the Oslo region are not more innovative than firms in other regions of Norway (Herstad et al., 2011). Previous research considered innovation as a general concept. Our study has corroborated and also nuanced this finding. We have considered relations 
between collaboration partners, sources of information and two different types of innovation, i.e. product and process innovations.

We have in many ways empirically tested the triple helix model by looking at the relationship between firms, universities and public support. Interestingly, we detected that public support of innovation is effective for product and process innovation. These latter two types may depend more upon internal and market-related characteristics that are not well captured in the CIS survey. Additionally we have not found support for the hypotheses that cooperation with universities is positively associated with any type of innovation in Norway.

Cooperation with suppliers was positively associated with process innovation, while cooperation with clients was positive for product innovation. Cooperation with consultants, competitors and universities was not positive for innovation at all. There may be underlying industry differences that we have not been able to control for, however.

Use of professional sources of information is still the most important for product innovation. Use of internal and university sources of innovation were not associated with any type of innovation, which in itself does not lend strong support neither for the triple helix perspective nor the model of open innovation. A clear message emerging from this study, and following a number of earlier investigations, is that openness and R\&D collaboration are not general (positive) phenomena related to innovation, but most likely related to characteristics of firms such as absorptive capacity and competence profiles that are not easily read from the CIS data (cf. Fritsch and Franke, 2004; Ebersberger and Herstad, 2011).

The evidence suggests that innovation should not be regarded as a homogeneous phenomenon. There are clear differences in the influences on the various types of innovation, and future studies on regional innovation need to conceptualize and consider the particular issues related to each type of innovation. As such our study makes several contributions. First, we integrate insights from the triple helix perspective with views with regards to open innovation and regional/local innovation systems, yet emerging with a critical message about the general claims often derived from the first two perspectives. Second, we challenge the view that governmental support generates equal benefits for both types of innovation. Two novel hypotheses relating to regional difference in use of governmental support and cooperation with universities and research institutions and firms are presented and tested for the first time. We hypothesized that there is a regional difference in use of support money and utilization of cooperation with universities. We have not found support for this hypothesis. However, we tested the influence of control and independent variables only on product and process innovation. Further 
research might explore the effect of different variables on organizational and market innovation.

\section{Implications for practitioners}

Our results are of interest to policymakers at regional and national levels. Government support may be central for the more technical types of innovation (process and product) and the early steps of creating new products. Our data leads us to the question of whether these policies will be effective. Similarly, there is a general tendency to support university-industry collaboration in many different innovation and R\&D support mechanisms. A "one size fits all" open, networked or triple helix innovation perspectives in designing policies and strategies may not have the desired effects.

\section{Implications for research}

Future research evidence is warranted here to guide collaboration decisions relating to the development of various types of innovation. This study has addressed several problems suggested by previous studies such as operationalization of innovation, the type of collaborations partners, and sources of information used to extract innovative ideas. Despite the key findings, our study is associated with limitations that provide opportunities for additional research attention. This study focused on cooperation with universities, commercial partners and governmental organizations in providing support for different types of innovations. The study did not consider whether collaboration benefits firms with fewer than 5 employees. We do not know how far smallest firms use governmental support and cooperate with others for development of innovative products. Previous research suggests that they should on one side actively use open innovation business models (Chesbrough, 2003). But on the other hand, the owners and managers of small firms are so busy that they do not have time and resources to participate in networking (Spithoven et al., 2010), and have limited absorptive capacity to 'digest' all innovative ideas which they meet (Laursen and Salter, 2006). Future research needs to address this issue in a longitudinal study. In particular, we recommend that later investigations look more closely at industry differences, an aspect difficult to scrutinize with the rather small samples from the different Norwegian regions.

Cross-sectional survey evidence was explored. Longitudinal studies focusing upon representative samples of small and large firms need to be provided. In line with previous studies (Fitjar and Rodriguez-Pose, 2013; Herstad et al., 2011), this study focused on regional difference in terms of innovation in the Norwegian context. Future studies need to monitor the 
income extracted from implementation of innovations, as well as a broad array of innovation outcome measures, and not solely the narrow measure relating to the implementation of different types of innovation. While most innovation studies have been conducted in Western contexts, future studies should consider impact of cooperation and governmental support in emerging economy contexts as well.

This study was limited to firms with 5 and more employees in Norway. Our findings might, therefore, be only limited in their generalizability beyond this context. Additional research is warranted to explore the external validity of presented findings with regard to other countries and smaller firms. Countries differ in terms of size, level of economic development, R\&D support, supply of natural resources, human resources, and other factors. Future studies could explore what specific types of innovation policy are most successful in encouraging firms to develop innovations.

\section{CONCLUSION}

We have sought to answer three research questions: How does cooperation with different actors affect innovation in firms? Are firms which cooperate with universities more likely to report differently on innovativeness than firms which do not cooperate with them?, and Are firms which get public support more likely to report differently on innovativeness than those which do not get support? In particular we have been interested in studying regional variation in Norway related to these questions. We have explored the role of cooperation with firms in the same enterprise group, suppliers, customers, competitors, and consultants. For the first question, we found out that cooperation with clients is positively and significantly related to product innovation and cooperation with suppliers is positively and significantly related to process innovation. Other forms of cooperation have little effect, including universities which do not emerge as significant partners for innovation in our data (question two). Use of professional sources of information is the most important for product innovation. Other sources of information were not significant for innovation.

Finally, for the third question we explored whether public support is related to actual innovation results, which is assumed to be essential during the innovation process. We found that firms receiving public support for $R \& D$ report higher levels of product and process innovation. Additionally, novel two-way interactions relating to six main Norwegian regions and innovation support as well as cooperation with universities (i.e., links between cooperation with university and specific benefits potentially generated by geographical 
location) were explored. Our regional variables were not significant in any of the regressions.

Our results provide words of cautions to simple applications of triple helix and open innovation frameworks. Only some types of university-industrygovernment interaction seem to be important and only for some types of innovation. We have not found evidence of a capital city effect, hypothesized as important due to the concentration of human capital and research and technology support systems, which may be due to particularities of the Norwegian innovation system. This is not necessarily because there is anything wrong with a collaborative approach to innovation. But the effects are likely to vary and to be more nuanced than what at least some of the interpretations of these approaches indicate. Many forms of collaboration seem to have little impact on innovation, regardless of regional context. This warrants additional research attention and further elaboration of triple helix and open innovation approaches. Future research can strengthen the generalizability of our findings by conducting cross-sectional and longitudinal evaluations of university-industry-government interaction in different national contexts and for more types than product and process innovations.

\section{References}

Acs, Z. J. (2002). Innovation and the Growth of Cities, Cheltenham: Edward Elgar.

Afuah, A. (2000). How Much Do Your Co-opetitors' Capabilities Matter in the Face of Technological Change? Strategic Management Journal, 21(3), 397-404.

Ahuja G. (2000). Collaboration Networks, Structural Holes and Innovation: a Longitudinal Study. Administrative Science Quarterly, 45(3), 425-455.

Almus, M., and Czarnitzki, D. (2003). The Effects of Public R\&D Subsidies on Firms' Innovation Activities: The Case of Eastern Germany. Journal of Business \& Economic Statistics, 21(2), 226-236.

Asheim, B. (2007). Differentiated Knowledge Bases and Varieties of Regional Innovation Systems. Innovation, 20(3), 223-241.

Asheim, B. and Coenen, L. (2005). Knowledge Bases and Regional Innovation Systems: Comparing Nordic Clusters, Research Policy, 34(8),1173-1190.

Asheim, B. and Gertler, M.S. (2005). The Geography of Innovation: Regional Innovation Systems. In: Fagerberg, J., Nelson, R.R. and Mowery, D.C. (Eds.), The Oxford Handbook of Innovation. Oxford: Oxford University Press.

Burton, R. M., and Obel, B. (2004). Strategic Organizational Diagnosis and Design: The Dynamics of Fit. , New York: Kluwer.

Chesbrough, H. W. (2003). Open Innovation: The New Imperative for Creating and Profiting From Technology. Harvard Business Press. 
Clausen, T. (2013). External Knowledge Sourcing From Innovation Cooperation and The Role of Absorptive Capacity: Empirical Evidence From Norway and Sweden, Technology Analysis \& Strategic Management, 25(1), 5770.

Dorfman, N. (1988). Route 128: The Development of a Regional High Technology Economy, In Lampe, D. (Ed.), The Massachusetts Miracle: High Tech and Economic Revitalization. Cambridge, MA: MIT Press.

Ebersberger, B., and Herstad, S. (2011). Product Innovation and the Complementarities of External Interfaces. European Management Review, 8(3), 117-135.

Enkel, E., Gassmann, O., and Chesbrough, H. (2009). Open R\&D and Open Innovation: Exploring the Phenomenon. R\&D Management, 39(4), 311316.

Etzkowitz, H. (2003). Innovation in innovation: The Triple Helix of Universityindustry-Government Relations. Social Science Information, 42(3), 293337.

Etzkowitz, H. and Leydesdorff, L. (1997). Universities and the Global Knowledge Economy: a Triple Helix of University-Industry-Government Relations. London: Pinter.

Etzkowitz, H. and Leydesdorff, L. (2000). The Dynamics of Innovation: From National Systems and 'Mode 2' To a Triple Helix of University-IndustryGovernment Relations, Research Policy, 29(2),109-123.

European Union (2014). Regional Innovation Scoreboard. Retrieved from: http://ec.europa.eu/enterprise/policies/innovation/policy/regionalinnovation/

Fitjar, R. D., and Rodríguez-Pose, A. (2013). Firm Collaboration and Modes Of Innovation In Norway. Research Policy, 42(1), 128-138.

Florida, R. (2002). The Rise Of The Creative Class And How it is Transforming Work, Leisure, Community, and Everyday Life. New York, NY: Perseus Book Group.

Fritsch, M., and Franke, G. (2004). Innovation, Regional Knowledge spillovers and R\&D Cooperation. Research Policy, 33(2), 245-255.

Fritsch, M. and Schwirten, C. (1999). Enterprise-University Cooperation and the Role of Public Research Institutions In Regional Innovation Systems. Industry and Innovation, 6(1), 69-83.

Gulbrandsen, M. and Solesvik, M. (2012). Comparing University-Industry Linkages in Two Industrial Clusters In Norway. Paper presented At The Regional Innovation Policy Conference in Porto, October 2012, Retrieved from: http://foreigners.textovirtual.com/rip2012-porto/2

Haskel, J., and Wallis, G. (2013). Public Support for Innovation, Intangible Investment and Productivity Growth in the UK Market Sector. Economics Letters, 119(2), 195-198.

Herstad, S., Aslesen, H. W., and Ebersberger, B. (2014). On Industrial Knowledge Bases, Commercial Opportunities and Global Innovation Network Linkages. Research Policy, 43(3), 495-504. 
Herstad, S., and Ebersberger, B. (2014). Urban Agglomerations, Knowledge Intensive Services and Innovation Activity: Establishing the Core Connections. Entrepreneurship \& Regional Development, 26(03-04), 211-233.

Herstad, S., Pålshaugen, $\varnothing$., and Ebersberger, B. (2011). Industrial Innovation Collaboration in a Capital Region Context. Journal of the Knowledge Economy, 2(4), 507-532.

Hewitt-Dundas, N., and Roper, S. (2010). Output Additionality of Public Support for Innovation: Evidence for Irish Manufacturing Plants. European Planning Studies, 18(1), 107-122.

Howells, J., James, A., and Malik, K. (2003). The Sourcing of Technological Knowledge: Distributed Innovation Processes and Dynamic Change. R\&D Management, 33(4), 395-409.

Huggins, R. (1998). Local Business Co-Operation and Training And Enterprise Councils: The Development of Inter-Firm Networks. Regional Studies, 32(9), 813-826.

Jaffe, A.B. (1989). Real Effects of Economic Research, American Economic Review, 79(5), 957-970.

Johansen, A. F. R., Rubach, S., Billington, M. G., Bye, G., Svare, H., and Solesvik, M. (2013). Nettverk Er Man Nødt Til Å Ha! Men Hva Kan Det Offentlige Bidra Med?. Plan: Tidsskrift for Samfunnsplanlegging, Byplan og Regional Utvikling, 12(6), 23-29

Laursen, K., and Salter, A. (2004). Searching High and Low: What Types of Firms Use Universities as a Source of Innovation?. Research Policy, 33(8), 1201-1215.

Laursen, K., and Salter, A. (2006). Open for Innovation: The Role of Openness in Explaining Innovation Performance among UK Manufacturing Firms. Strategic Management Journal, 27(2), 131-150.

Laursen, K., Masciarelli, F., \& Prencipe, A. (2012a). Regions Matter: How Localized Social Capital Affects Innovation and External Knowledge Aquisition. Organization Science, 23(1), 177-193.

Laursen, K., Masciarelli, F., \& Prencipe, A. (2012b). Trapped or Spurred by the Home region? The Effects of Potential Social Capital on Involvement in Foreign Markets for Goods and Technology. Journal of International Business Studies, 43(9), 783-80

Laursen, K., Reichstein, T., \& Salter, A. (2011). Exploring the Effect of Geographical Proximity and University Quality on University-Industry Collaboration in the United Kingdom. Regional Studies, 45(4), 507-523.

Lester, R. (2005) Universities, Innovation, and the Competitiveness of Local Economies. a Summary Report from the Local Innovation Systems Project - Phase 1. Boston, MA: MIT.

Mitra, J. (2012). Entrepreneurship, Innovation and Regional Development: An Introduction. Oxon: Routledge. 
Mol, M. J., and Birkinshaw, J. (2009). The Sources of Management Innovation: When Firms Introduce New Management Practices. Journal of Business Research, 62(12), 1269-1280.

OECD (2008). Reviews of Innovation Policy: Norway. Paris: OECD.

Productivity Commission. (2007). Public Support for Science and Innovation. Productivity Commission, Government of Australia Research Reports.

Putnam, R.D. (1993). Making Democracy Work: Civic Traditions in Modern Italy. Princeton, NJ: Princeton University Press.

Reichwald, R. and Piller, F. (2009). Interaktive Wertschöpfung: Open Innovation, Individualisierung und Neue Formen der Arbeitsteilung. Bering, Heidelberg: Springer.

Segal, N.S. (1988). The Cambridge Phenomenon: Universities, Research, and Local Economic Development In Great Britain, In Smilor, R.W., Kozmetsky, Gibson, D.V. (eds.), Creating the Technolpolis. Cambridge, MA: Ballinger.

Smilor, R.W., Kozmetsky, and Gibson, D.V. (1988). The Austin/San Antonio Corridor, The Dynamics Of a Developing Technopolis, In: Smilor, R.W., Kozmetsky, Gibson, D.V. (Eds.), Creating the Technolpolis. Cambridge, MA: Ballinger.

Solesvik, M. and Gulbrandsen, M. (2013). Partner Selection for Open Innovation. Technology Innovation Management Review, 8(4), 11-16.

Spithoven, A., Clarysse, B., and Knockaert, M. (2010). Building Absorptive Capacity to Organise Inbound Open Innovation in Traditional Industries. Technovation, 30(1), 130-141.

SSB (2014). Standard for næringsgruppering (SN2007). Retrieved from http:// stabas.ssb.no/ItemsFrames.asp?ID $=8118001$ \& Language $=\mathrm{nb}$

Strand, $\varnothing$., and Leydesdorff, L. (2013). Where is synergy indicated in the Norwegian innovation system? Triple-Helix relations among technology, organization and geography. Technological Forecasting and Social Change, 80, 417-484.

Tether, B. S. (2002). Who Co-operates for Innovation, and Why: An Empirical Analysis. Research Policy, 31(6), 947-967.

Vahter, P., Love, J. H., and Roper, S. (2012). Openness and Innovation Performance: Are Small Firms Different? Coventry: Warwick Business School.

von Hippel, E. (1988). The Sources of Innovation. Oxford University Press: New York.

\section{Abstrakt (in Polish)}

Na podstawie dotychczasowych badań nad wspótpraca $w$ dziedzinie innowacji na poziomie regionu oraz w oparciu o teoretyczne koncepcje potrójnej helisy, lokalnych i regionalnych systemów innowacji i innowacji otwartej, w artykule bada się czy wspótpraca między firmami, uniwersytetami i władzami publicznymi w równym stopniu zwiększa innowacyjność przedsiębiorstw w stolicy Norwegii i w regionach peryferyjnych. Analizuje się ponadto, czy norweskie firmy zlokalizowane $w$ regionie 
stołecznym w większym stopniu korzystajq ze wsparcia publicznego, współpracy $z$ uniwersytetami i z innymi interesariuszami, niż firmy zlokalizowane na peryferii. $\mathrm{Na}$ podstawie logistycznej regresji binarnej wykazano, że przedsiębiorstwa $z$ regionu stołecznego nie sq generalnie bardziej innowacyjne, niż firmy z innych lokalizacji. Ponadto, nie stwierdzono, aby współpraca z uniwersytatami wpływała na innowacyjność, jakkolwiek występuje zależność między korzystaniem ze wsparcia publicznego i innowacyjnościq w zakresie produktu i procesu. Wyniki badań sugerujq, że należy unikać uproszczeń w stosowaniu koncepcji potrójnej helisy i innowacji otwartej, gdyż wiele form współpracy wydaje się mieć ograniczony wpływ na powstawanie innowacji, niezależnie od kontekstu regionalnego.

Słowa kluczowe: innowacja, współpraca, potrójna helisa, regionalne systemy innowacji, Norwegia.

\section{Biographical notes}

Marina Z. Solesvik is a professor of Innovation and Management at the Stord/ Haugesund University College. She also holds part-time positions as professor at the University of Troms $\varnothing$, University of Nordland and Bergen University College (Norway). She is also a board member at several Norwegian firms and organizations. Marina holds a PhD in Management from the Graduate Business School at the University of Nordland and PhD in Entrepreneurship from the Institute of Agrarian Economy in Kiev, Ukraine. Her research interests include regional innovation, open innovation, maritime business, entrepreneurial intentions, female entrepreneurship, strategic alliances, and Arctic research.

Magnus Gulbrandsen is a professor and a leader of the Innovation group at the Center of Technology, Innovation and Culture (TIK) at the University of Oslo. His research topics have included the role of public research organizations in innovation, commercialization of research and universityindustry relationships, the nature and legitimacy of research institutes, internationalization of R\&D and innovation, quality in science, and the organization and funding of research work in different settings. He has an extensive publishing record and has also worked as a contract researcher and consultant. 